\title{
Knowledge of $B t$ Cotton Growers for Control of Pink Bollworm
}

\author{
A. M. Todkar*, S. R. Jakkawad and S. B. Khodake \\ Department of Extension Education, College of Agriculture, Parbhani (M.S.), India \\ *Corresponding author
}

\begin{abstract}
A B S T R A C T
\section{Keywords}

Bt gene, Pink bollworm,

knowledge,

Pheromone trap etc

Article Info

Accepted:

18 November 2020

Available Online:

10 December 2020

The present study on knowledge of Bt cotton growers for control of pink bollworm was conducted in Parbhani district of Marathwada region in Maharashtra State. The data were collected through personal interview with the help of interview schedule by contacting 120 respondents. The data was processed by making primary and secondary tables. The information of qualitative nature was converted into quantitative from form and computation of score was done for each of the independent and dependent variables. The study showed that, majority $(66.66 \%)$ of the farmers had medium level knowledge while other 33.33 per cent of farmers belongs to high knowledge level category. Whereas, no per cent of farmers belongs to low knowledge level category of about control pink bollworm in cotton crop. Variable like annual income, area under $B t$ cotton, source of irrigation and risk orientation found to be had positive and significant relationship with the knowledge of respondents for control of pink bollworm. While social participation, farming experience, source of information, extension contact, innovativeness, economic motivation found positive and highly significant with knowledge of respondents for control pink bollworm. Whereas variable like age and land holding found non-significant relationship with knowledge of respondents and education observed to be negatively significant with knowledge of respondents.
\end{abstract}

\section{Introduction}

Cotton the 'White Gold' is played a vital role in updating Indian economy and evolution of human ethical, moral and cultural values. Although the cotton is primarily a fiber crop, the oil that it contains is used in cosmetic products and in certain food products. Cotton plays a key role in national economy in terms of both employment generations and foreign exchange earnings. Cotton is a basic raw material for Textile Industry. The Indian Textile Industry has an overwhelming presence in the economic life of the Country. Apart from providing one of the basic necessities of life, the Textile Industry also plays a pivotal role through its contribution to industrial output, employment generation and export earnings of the Country.

Control of pink bollworm can be done by various tools in a way that minimizes economic, health and environmental risks. Control involves an eliminate or prevents pest problems before they established. Pink bollworm has now emerged as a major pest of 
cotton in all cotton growing areas in India. The pest mainly fed on seeds causing economic loss. Infestation occurs in mid and late stages of the crop; it remains undetected due to feeding behavior and causes loss of yield quality. It impacts boll opening, coinciding with the second picking of cotton in most areas. Since the last 2-3 years, pink bollworm is appearing early (45-60 days after sowing) on $B t$ cotton hybrids in Central and South India.

\section{Results and Discussion}

The study was conducted in randomly selected Parbhani district of Marathwada region.
In Parbhani district there are 9 talukas. Out of these three talukas Parbhani, Purna and Pathri was selected randomly as area and infestation of pink bollworm was more in these region. The names of villages which come under the selected talukas were collected from the secondary source. To obtain the desired no of respondent of villages this comes under Parbhani district. Ten $B t$ cotton growers were selected randomly from each village to comprise the sample of 120 respondents for study. Respondents were selected according to the considerable area under $B t$ cotton growers. The study sample consists of having 120 respondents from three talukas. The Data were analyze by using mean, S.D., and coefficient of correlation methods were used for data analysis (Fig. 1).

Table.1 Distribution of respondents Knowledge for control of pink bollworm

\begin{tabular}{|c|c|c|c|}
\hline Sr. No. & Category & Frequency & Per cent \\
\hline $\mathbf{1 .}$ & Low (Up to 2$)$ & 00 & 00.00 \\
\hline $\mathbf{2 .}$ & Medium $(2$ to 8$)$ & 40 & 66.66 \\
\hline $\mathbf{3 .}$ & High (Above 8 ) & 80 & 33.33 \\
\hline & Total & $\mathbf{1 2 0}$ & $\mathbf{1 0 0 . 0 0}$ \\
\hline
\end{tabular}

Fig.1 Distribution of respondents according to their knowledge for control of pink bollworm

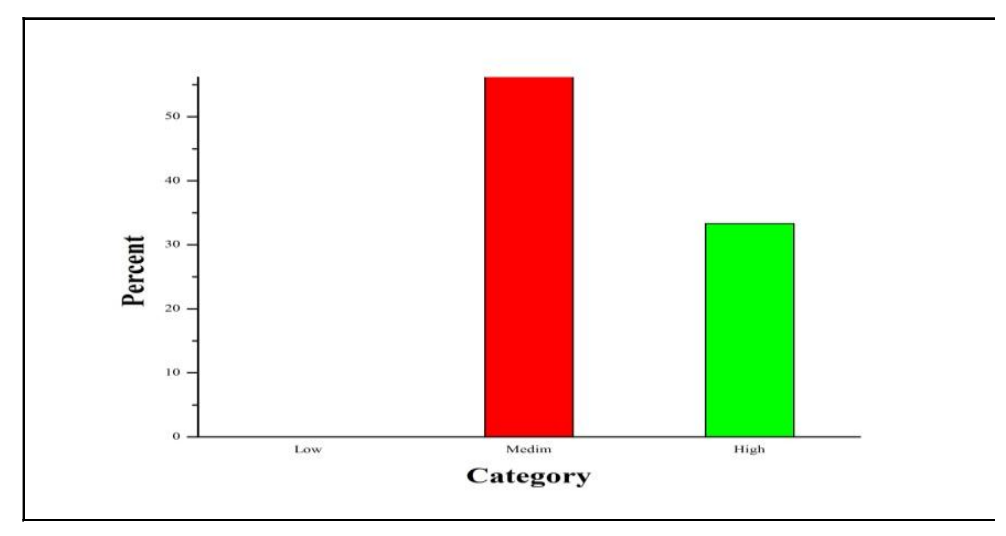

\section{Observation and analysis}

The findings of the study as well as discussion have been showed in table 1 .
From the data reported in above Table 1 that majority $(66.66 \%)$ of the farmers had medium level knowledge while other 33.33 per cent of farmers belong to high knowledge level category. Whereas, no per cent of farmers 
belongs to low knowledge level category of about control pink bollworm in cotton crop.

In conclusion the study observed that the majority $(66.66 \%)$ of the farmers had medium level knowledge while other 33.33 per cent of farmers belong to high knowledge level category. Whereas, no per cent of farmers belongs to low knowledge level category of about control pink bollworm in cotton crop.

\section{References}

Gohil G.R., Nakum P.B., Kalsariya B.N. and Patel R.I. (2016). Knowledge level of cotton growers about crisis management for cotton cultivation. Volume 8(25):1503-1505.

Dodiya, H.D, Patel J.K., Prajapati M.R. and Patel V.T. (2016). Knowledge and Attitude Of Bt. Cotton Growers About Integrated Pest Management. Volume 8(25):1511-1513.

Sable, B. D. and Kadam, R. P. (2012). Adoption gap in integrated pest management technology of cotton. Internat. J. Plant Protec., 5 (2): 352355 .

\section{How to cite this article:}

Todkar, A. M., S. R. Jakkawad and Khodake, S. B. 2020. Knowledge of Bt Cotton Growers for Control of Pink Bollworm. Int.J.Curr.Microbiol.App.Sci. 9(12): 2728-2730.

doi: https://doi.org/10.20546/ijcmas.2020.912.324 